\title{
Alkali metal actinide complex halides : thermochemical and structural considerations
}

\author{
J. Fuger \\ Institute of Radiochemistry, University of Liège, Sart Tilman, B-4000 Liège, Belgium
}

\begin{abstract}
Résumé. - L'auteur passe en revue l'état actuel de nos connaissances dans le domaine de la thermodynamique des complexes halogénés d'actinides avec les ions alcalins, en portant une attention toute spéciale aux dérivés chlorés et bromés.

Lorsque les données thermodynamiques et structurales sont accessibles, il tente de déduire l'évolution de l'énergie de la liaison actinide-halogène au sein d'une série de composés isomorphes ou analogues.

Enfin, la variation énergétique au cours de la formation du complexe halogéné à partir des halogénures binaires d'actinides et de métaux alcalins est prise pour base en vue de prévoir la stabilité de composés nouveaux, spécialement ceux pour lesquels l'halogénure binaire d'actinide n'a pas été préparé ou est de faible stabilité. Diverses méthodes de préparation sont évoquées.
\end{abstract}

\begin{abstract}
The present status of our information on the thermodynamics of the actinide halogeno-complexes with alkali metal ions is reviewed, with special emphasis on chloro- and bromo-derivatives.

Where enough thermodynamic and structural data are available, attempts are made to deduce the evolution of the energetics of the actinide-halogen bonds along a series of isomorphous or analogous compounds.

The energy change upon the formation of the halogeno-complexes from binary actinide halides and alkali metal halides is discussed with the aim of predicting the stability of new compounds, especially those for which the corresponding binary actinide halides have not been characterized or are of low stabilities. Possible preparative routes for such compounds are also outlined.
\end{abstract}

1. Introduction. - For many years the halogenocomplexes of the actinides, as well as those of the lanthanides and of $d$ transition and main group elements have received considerable interest from the inorganic and the physical chemist. It is probably significant to indicate that at the Second International Conference on the Electronic Structure of the Actinides in Wrockaw (1976) four papers were devoted to this topic: these papers, however, were essentially oriented toward spectral and magnetic studies, leading to energy levels of the actinide cation in a highly symmetrical environment of halide anions. Structural chemistry of these compounds has also received a lot of attention and has shown that quite often the coordination about the actinide in a complex halide is not the same as in the binary halide. On the other hand our information on the thermochemical properties is quite fragmentary: This may appear surprising since such data are needed to fully understand the very existence of such compounds. The stabilization observed upon formation of such complex halides from the binary salts is itself a source of valuable information with respect to the obtention of new compounds for which the binary salt either cannot be obtained or is of very low stability. Finally, on a practical point of view, these halogeno-complexes of ten provide the actinides in a wide choice of oxidation states, in the form of compounds which are easier to prepare (for instance via aqueous rather than via dry method) or to handle (because they are less hygroscopic) than the binary halides.

In the present paper we shall restrict our considerations to halogeno-complexes and oxyhalogenocomplexes involving alkali metal ions ('), as thermodynamic data on complexes with organic univalent cations are simply not existent and since our overall information on complexes with other metal ions are of relative paucity.

2. Fluoro-complexes. - A very large number of actinide fluoride complexes have been characterized, in which the actinide cation is displaying a coordination which can vary from 6 to 9 , and preparative, structural and spectral studies on these compounds have adequately been reviewed [1-3]. Our knowledge on the enthalpies of formation of such species is so far restricted to a number of uranyl compounds [4-6] with the general formulae $\mathrm{M}_{3}^{\prime} \mathrm{UO}_{2} \mathrm{~F}_{5} . \mathrm{M}^{\prime}\left(\mathrm{UO}_{2}\right)_{2} \mathrm{~F}_{5}$ and $\mathrm{M}_{5}^{\prime}\left(\mathrm{UO}_{2}\right)_{2} \mathrm{~F}_{9}\left(\mathrm{M}^{\prime}\right.$ variously $\mathrm{Na}, \mathrm{K}, \mathrm{Rb}$ and $\mathrm{Cs}$ ). We have also at disposal information on the complex compounds of $\mathrm{UF}_{6}$ with $\mathrm{NaF}: \mathrm{NaUF}_{7}, \mathrm{Na}_{2} \mathrm{UF}_{8}$ and the controversial $\mathrm{Na}_{3} \mathrm{UF}_{9}$ [7-10] ; however, quantitative thermodyna-

(') The ammonium cation, which often behaves like an alkali metal ion will not be considered here. We have also disregarded the numerous alkali metal hydrated complexes. 
mic data on fluoride complexes of uranium in a valency state other than six or on complex fluorides of other actinides are essentially lacking except for studies on the interaction of alkali metal fluorides with $\mathrm{PuF}_{6}[11]$.

Under such conditions the establishment of thermodynamic interrelationships with fluorocomplexes seems premature.

3. Chloro- and bromo-complexes. - Here, our information is much broader and, in fact, as early as 1911, Chauvenet [12] obtained results on the enthalpies of formation of various chloro-complexes of thorium (IV) with the general formula $\mathrm{M}^{\prime} \mathrm{ThCl}_{5}$, $\mathrm{M}_{2}^{\prime} \mathrm{ThCl}_{6}$ and $\mathrm{M}_{4}^{\prime} \mathrm{ThCl}_{8}$, from the comparison of the enthalpies of solution in water of the binary halides of these chloro-complexes. In a study involving the various actinide (IV) compounds of the type $\mathrm{Cs}_{2} \mathrm{MCl}_{6} \quad(\mathrm{M}=\mathrm{Th}$ to $\mathrm{Pu}$ inclusive $)$ Fuger and Brown $[13,14]$ obtained results in good agreement with those of Chauvenet for the thorium salt. On the other hand, Martynova et al. and Vdovenko et al. reported results for the enthalpies of formation of various alkali metal uranium (IV) chlorocomplexes $[15,16]$ and bromo-complexes $[17,18]$.
More recently similar data were obtained on the newly characterized compounds $\mathrm{Cs}_{2} \mathrm{NpBr}_{6}$ and $\mathrm{Cs}_{2} \mathrm{PuBr}_{6}$ by Magette and Fuger [19] and Niffle and Fuger [20]. Table I lists the recently assessed values [21] for the standard enthalpies of formation at $298 \mathrm{~K}$ of the various actinide (IV) chloro- and bromo-complexes, according to reaction (1)

$$
\begin{aligned}
x \mathrm{M}^{\prime}(\mathrm{c})+\mathrm{M}(\mathrm{c})+\frac{4+x}{2} & \mathrm{X}_{2}(\mathrm{~g} \text { or } 1) \rightarrow \\
& \rightarrow \mathrm{M}_{x}^{\prime} \mathrm{MX}_{4+x}(\mathrm{c}), \Delta H_{\mathrm{f}}^{0}
\end{aligned}
$$

where $M^{\prime}, M$ and $X_{2}$ are, respectively, the alkali metal, the actinide and the halogen in their standard state at $298 \mathrm{~K}$ : crystalline (c), liquid (1) and gaseous (g). These values are consistent with the latest auxiliary data recommended by CODATA [22] or compatible with the CODATA selection [23]. Table I lists also the best values for the enthalpies of formation, $\Delta H_{\text {complex }}$, from the binary salts, according to reaction (2)

$$
x \mathrm{M}^{\prime} \mathrm{X}(\mathrm{c})+\mathrm{MX}_{4}(\mathrm{c}) \rightarrow \mathrm{M}_{x}^{\prime} \mathrm{MX}_{4+x}(\mathrm{c}), \quad \Delta H_{\text {complex }}
$$

Table I. - Thermodynamic data associated with the formation of quadrivalent actinide chloro- and

\begin{tabular}{|c|c|}
\hline \multirow{2}{*}{$-\Delta H_{\text {complex }}$} & which data are based \\
\hline & \\
\hline $24.7 \pm 3.8$ & Chauvenet [12] \\
\hline $25.9 \pm 2.5$ & Martynova $[15]$; Vdovenko $[16]$ \\
\hline $43.9 \pm 3.3$ & Vdovenko [16] \\
\hline $56.9 \pm 3.3$ & Vdovenko $[16]$ \\
\hline $35.6 \pm 5.9$ & Chauvenet [12] \\
\hline$-4.6 \pm 2.5$ & Vdovenko [16] \\
\hline $32.6 \pm 5.9$ & Chauvenet [12] \\
\hline $6.7 \pm 2.5$ & Martynova [15] ; Vdovenko [16] \\
\hline $25.1 \pm 2.5$ & Martynova $[15]$ \\
\hline $51.9 \pm 5.9$ & Chauvenet $[12]$ \\
\hline $40.2 \pm 2.5$ & Martynova $[15]$; Vdovenko [16] \\
\hline $101.3 \pm 5.9$ & Chauvenet [12] \\
\hline $67.4 \pm 2.5$ & Vdovenko [16] \\
\hline $137.2 \pm 8.0$ & Chauvenet [12] \\
\hline $69.0 \pm 3.3$ & Vdovenko $[16]$ \\
\hline $76.1 \pm 1.3$ & Chauvenet [12]; Fuger, Brown [13] \\
\hline $99.6 \pm 1.3$ & Fuger, Brown [14] \\
\hline $107.1 \pm 3.3$ & Fuger, Brown [13]; Vdovenko [16] \\
\hline $108.1 \pm 0.6$ & Fuger, Brown [13] \\
\hline $120.1 \pm 8.0)$ & Fuger, Brown [13] \\
\hline $96.2 \pm 8.0$ & Chauvenet [12] \\
\hline $5.3 \pm 0.9$ & Vdovenko [18] \\
\hline $43.6 \pm 0.9$ & Vdovenko [18] \\
\hline $62.2 \pm 0.6$ & Vdovenko $[17]$ \\
\hline $96.3 \pm 0.6$ & Vdovenko [17] \\
\hline $100.4 \pm 0.7$ & Magette, Fuger [19] \\
\hline $127.6 \pm 8.0)$ & Niffle, Fuger [20] \\
\hline $54.8 \pm 5.9$ & Vdovenko [16] \\
\hline
\end{tabular}
bromo-complexes at $298 \mathrm{~K}\left(\mathrm{~kJ} . \mathrm{mol}^{\sim 1}\right)$.

\begin{tabular}{lc}
\multicolumn{1}{c}{$\mathrm{Compound}_{1}$} & $-\Delta H_{\mathrm{f}}^{0}$ \\
$\mathrm{LiThCl}_{5}$ & $1619.6 \pm 4.2$ \\
$\mathrm{KuCl}_{5}$ & $1481.1 \pm 3.3$ \\
$\mathrm{RbUCl}_{5}$ & $1497.9 \pm 4.2$ \\
$\mathrm{CsUCl}_{5}$ & $1518.4 \pm 4.2$ \\
$\mathrm{Li}_{2} \mathrm{ThCl}_{6}$ & $2038.9 \pm 6.3$ \\
$\mathrm{Li}_{2} \mathrm{UCl}_{6}$ & $1831.3 \pm 3.8$ \\
$\mathrm{Na}_{2} \mathrm{ThCl}_{6}$ & $2041.4 \pm 6.3$ \\
$\mathrm{Na}_{2} \mathrm{UCl}_{6}$ & $1848.1 \pm 3.8$ \\
$\mathrm{NaKUCl}_{6}$ & $1891.6 \pm 3.8$ \\
$\mathrm{~K}_{2} \mathrm{ThCl}_{6}$ & $2110.8 \pm 6.3$ \\
$\mathrm{~K}_{2} \mathrm{UCl}_{6}$ & $1931.8 \pm 3.8$ \\
$\mathrm{Rb}_{2} \mathrm{ThCl}_{6}$ & $2157.3 \pm 6.3$ \\
$\mathrm{Rb}_{2} \mathrm{UCl}_{6}$ & $1956.0 \pm 3.8$ \\
$\mathrm{Rb}_{4} \mathrm{ThCl}_{8}$ & $3063.5 \pm 8.0$ \\
$\mathrm{Rb}_{4} \mathrm{UCl}_{8}$ & $2828.0 \pm 4.2$ \\
$\mathrm{Cs}_{2} \mathrm{ThCl}_{6}$ & $2147.6 \pm 2.1$ \\
$\mathrm{Cs}_{2} \mathrm{PaCl}_{6}$ & $2029 \pm 13$ \\
$\mathrm{Cs}_{2} \mathrm{UCl}_{6}$ & $2011.2 \pm 4.2$ \\
$\mathrm{Cs}_{2} \mathrm{NpCl}_{6}$ & $1977.4 \pm 1.7$ \\
$\mathrm{Cs}_{2} \mathrm{PuCl}_{6}$ & $1972.8 \pm 2.9$ \\
$\mathrm{Cs}_{4} \mathrm{ThCl}_{8}$ & $3053.1 \pm 8.0$ \\
$\mathrm{Na}_{2} \mathrm{UBr}_{6}$ & $1529.7 \pm 2.5$ \\
$\mathrm{~K}_{2} \mathrm{UBr}_{6}$ & $1632.6 \pm 2.5$ \\
$\mathrm{Rb}_{2} \mathrm{UBr}_{6}$ & $1653.3 \pm 3.3$ \\
$\mathrm{Cs}_{2} \mathrm{UBr}_{6}$ & $1710.0 \pm 3.3$ \\
$\mathrm{Cs}_{2} \mathrm{NpBr}_{6}$ & $1682.5 \pm 1.9$ \\
$\mathrm{Cs}_{2} \mathrm{PuBr}_{6}$ & $1694.1 \pm 3.6$ \\
$\mathrm{CsU}_{2} \mathrm{Cl}_{9}$ & $2535.1 \pm 8.0$
\end{tabular}

$\left(^{*}\right)$ When there are more than two authors, only the first one is indicated. 
The evaluation of $\Delta H_{\text {complex }}$ is obtained from the comparison of the enthalpies of solution of the complex halides and of the binary halides in the same media. In a number of instances the reported data arise from measurements by two groups of authors. The agreement between these sets of results is good as it can be inferred from the indicated uncertainty limits. The values are also in agreement with the recently assessed enthalpies of formation of the actinide tetrahalides [21]. The results of Martynova et al., Vdovenko et al. and Fuger et al. clearly show for both the uranium chloro- and bromocomplexes a steady change in $\Delta H_{\text {complex }}$ with the increasing size of the alkali metal cation from $+5 \mathrm{~kJ} . \mathrm{mol}^{-1}$ for a salt such as $\mathrm{Li}_{2} \mathrm{UCl}_{6}$ to ca. $-100 \mathrm{~kJ} \cdot \mathrm{mol}^{-1}$ for $\mathrm{Cs}_{2} \mathrm{UX}_{6}$ salts. The same trend is observed in the case of the uranyl fluorocomplexes [4-6]. The early data of Chauvenet on thorium compounds, however, do not seem to obey such a simple pattern. On the other hand, where data are available for a series of actinides, essentially the dicaesium compounds, an increase is also observed in the stability of the complex salt with regard to the binary salts with the decreasing ionic size of the actinide cation. In the case of $\mathrm{Cs}_{2} \mathrm{PuCl}_{6}$ and $\mathrm{Cs}_{2} \mathrm{PuBr}_{6}$, as neither $\mathrm{PuCl}_{4}$ nor $\mathrm{PuBr}_{4}$ have been characterized as solid compounds, $\Delta H_{\text {complex }}$ has been obtained from an estimate of the enthalpy formation of these hypothetical tetrahalides based on the extrapolation of the well known enthalpies of solution of the lighter actinide tetrahalides and on the enthalpies of formation of the tetravalent actinide ions [26].

As our information on the thermochemistry of the $\mathrm{Cs}_{2} \mathrm{MX}_{6}$ compounds is now relatively abundant we have attempted to gain some insight on the evolution of the enthalpic effect, through the actinide series, for the formal process described by reaction (3)

$$
\begin{aligned}
\mathrm{M}(\mathrm{c})+3 \mathrm{X}_{2}(\mathrm{~g} \text { or } 1) & +2 \mathrm{e}^{-} \rightarrow \\
& \rightarrow \mathrm{MX}_{6}^{2-}(\mathrm{g}), \Delta H_{\mathrm{f}}^{0}\left(\mathrm{MX}_{6}^{2-}, \mathrm{g}\right)
\end{aligned}
$$

and corresponding to the standard enthalpy of formation of $\mathrm{MX}_{6}^{2-}(\mathrm{g})$, as well as for the process described by reaction (4)

$$
\mathrm{M}(\mathrm{g})+4 \mathrm{X}(\mathrm{g})+2 \mathrm{X}^{-}(\mathrm{g}) \rightarrow \mathrm{MX}_{\kappa}^{2-}(\mathrm{g}), \quad 6 \Delta H_{\mathrm{s}}(\mathrm{M}-\mathrm{X})
$$

$\Delta H_{f}(\mathrm{M}-\mathrm{X})$ being the average enthalpy change upon formation of one $\mathrm{M}-\mathrm{X}$ bond in $\mathrm{MX}_{6}^{2-}(\mathrm{g})$ from the specified gaseous species. The quantities can be evaluated through the use of a classical Born-Haber cycle as shown in figure 1 . In this cycle $\Delta H_{\mathrm{f}}^{0}(\mathrm{M}, \mathrm{g})$ is the standard enthalpy of sublimation of the actinide metal, as recently assessed [26] and listed in table III ; $\Delta H_{\mathrm{f}}^{0}(\mathrm{Cs}, \mathrm{g})$, the standard enthalpy of subli-

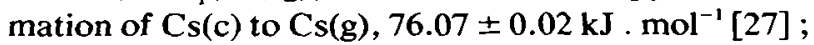
$I(\mathrm{Cs}, \mathrm{g})$, the first ionization potential of caesium, $375.7 \mathrm{~kJ} . \mathrm{mol}^{-1}[28] ; \Delta H_{\mathrm{f}}^{\mathrm{o}}(\mathrm{X}, \mathrm{g})$, the standard enthalpy of formation of monoatomic halogen gas, $121.302 \pm 0.008 \mathrm{~kJ} \cdot \mathrm{mol}^{-1}$ for $\mathrm{Cl}$ and $111.86 \pm$

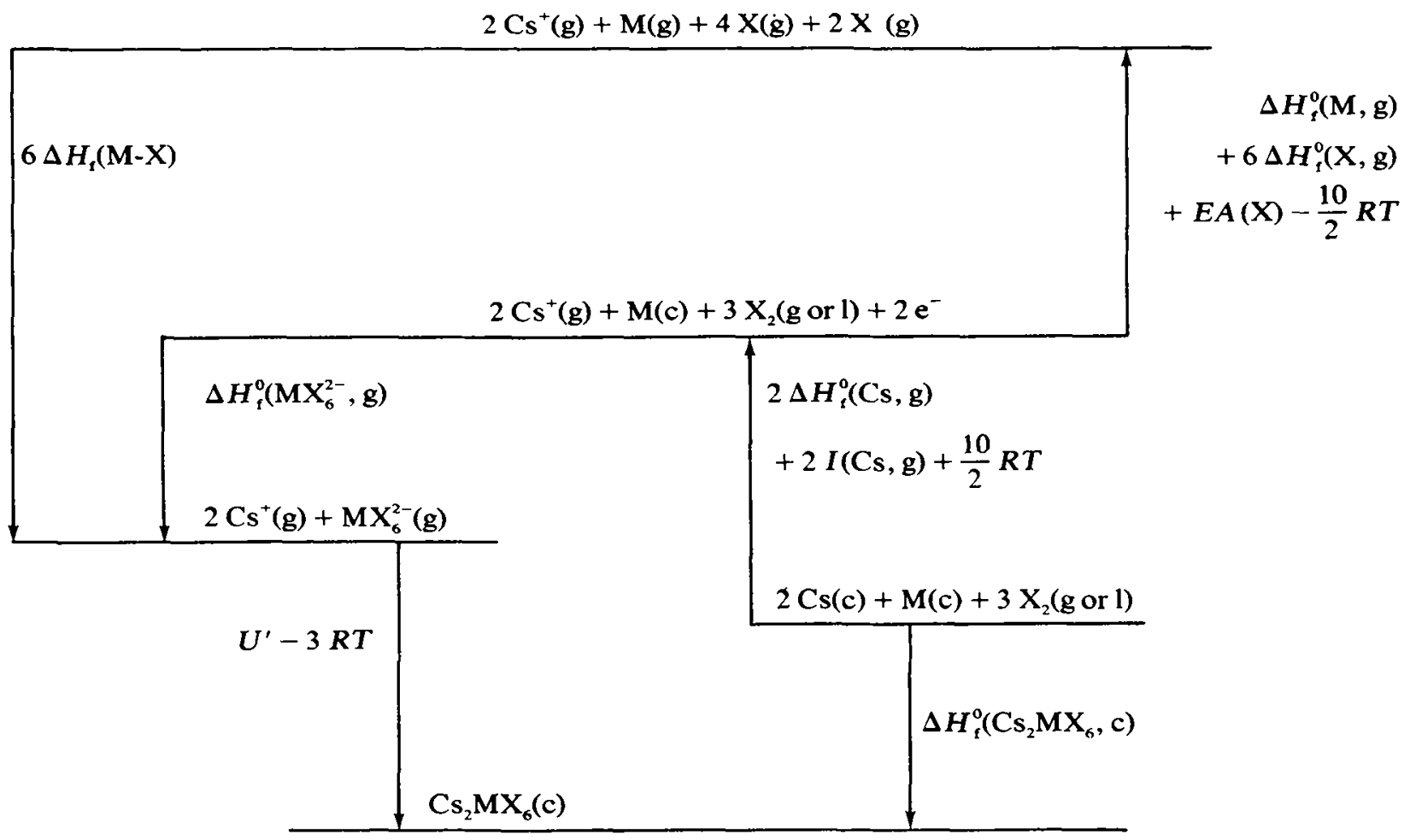

Fig. 1. - Enthalpy cycle for $\mathrm{Cs}_{2} \mathrm{MX}_{0}$. 
$0.12 \mathrm{~kJ} \cdot \mathrm{mol}^{-1}$ for $\mathrm{Br}$ [22]; $E A(\mathrm{X})$, the electron affinity of the halogen, $-348.8 \pm 0.4 \mathrm{~kJ} \cdot \mathrm{mol}^{-1}$ for $\mathrm{Cl}$ and $-324.60 \pm 0.4 \mathrm{~kJ} \cdot \mathrm{mol}^{-1}$ for $\mathrm{Br}[29] ; \frac{10}{2} R T$ is the enthalpic term corresponding to the formation of two moles of gaseous electrons ; $U^{\prime}$ is the lattice energy, i.e. the total change in internal energy upon formation of one mole of $\mathrm{Cs}_{2} \mathrm{MX}_{6}(\mathrm{c})$ from two moles of $\mathrm{Cs}^{+}(\mathrm{g})$ and one mole of $\mathrm{MX}_{\kappa}^{2-}(\mathrm{g}),-3 R T$ being the corresponding PV work.

Although realizing limitations of such relationships, but having only in mind to evaluate the trend in $\Delta H_{1}^{0}\left(\mathrm{MX}_{6}^{2-}, \mathrm{g}\right)$ and $\Delta H_{\mathrm{f}}(\mathrm{M}-\mathrm{X})$ along a series of analogous compounds we have chosen to use for the estimation of the lattice energy the semi-empirical relationship of Kapustinskii as modified by Yatsimirskii [30] and applicable to salts formed by cations having an outer shell of eight electrons

$$
\begin{aligned}
U^{\prime}\left(\mathrm{kJ} . \mathrm{mol}^{-1}\right)= & -1201.6 \frac{n Z_{\mathrm{c}} Z_{\mathrm{a}}}{r_{\mathrm{c}}+r_{\mathrm{s}}} \times \\
& \times\left[1-\frac{0.345}{r_{\mathrm{c}}+r_{\mathrm{a}}}+0.0087\left(r_{\mathrm{c}}+r_{\mathrm{s}}\right)\right]
\end{aligned}
$$

in which $n$ is the number of ions in the molecule of the salt, $Z_{c}$ and $Z_{\mathrm{a}}$ are the formal charges of the cation $\left(\mathrm{Cs}^{+}\right)$and of the anion $\left(\mathrm{MX}_{6}^{2}\right)$ and $r_{\mathrm{c}}$ and $r_{2}$ are the radii $(\AA)$ of the cation and of the anion respectively.
In the case of the $\mathrm{Cs}_{2} \mathrm{MCl}_{6}$ salts, which have a trigonal structure $\left(D_{3 d^{-}}^{3} C^{\frac{2}{3}} \mathrm{~m}\right)$, the value of $r_{c}+r_{\mathrm{a}}$ is deduced from the formula proposed by Yatsimirskii [31]:

$$
r=r_{\mathrm{c}}+r_{\mathrm{a}}=\frac{11.85}{\sqrt[3]{\frac{1000 \mathrm{nd}}{M}}}
$$

in which $d$ is the density of the compound $\left(\mathrm{g} . \mathrm{cm}^{-3}\right)$ and $M$ its molecular weight. The corresponding hexabromo-compounds of uranium, neptunium and plutonium exhibit the fcc $\mathrm{K}_{2} \mathrm{PtCl}_{6}$ structure $\left(\mathrm{O}_{\mathrm{h}}^{3}\right.$ $\mathrm{Fm} 3 \mathrm{~m})$. In that case we have taken for $r$ the interatomic distance between the actinide and the caesium (both fixed by symmetry) as calculated from the lattice parameter. Let us note, however, that application of relationship (6) above leads for these compounds to values of $r$ which are within $1 \%$ of the selected values. These various structural data are listed in table II.

The results of the thermodynamic calculations are listed in table III, together with $\Delta H_{\mathrm{f}}^{\mathrm{o}}(\mathrm{M}, \mathrm{g})$.

These data clearly show, with the increase of the atomic number of the actinide, a steady decrease in the enthalpy effects associated with the formation of each $\mathrm{MX}_{0}^{2-}(\mathrm{g})$ species. On the other hand, through similar calculations, Vdovenko et al. $[16,18]$ showed that in the case of the chloro- and bromo-uranates, the energetics of the $M-X$ bond is virtually independent of the nature of the alkali metal cation.

Table II. - Structural data on $\mathrm{Cs}_{2} \mathrm{MX}_{6}$ compounds.

\begin{tabular}{|c|c|c|c|c|}
\hline & $-U^{\prime}$ & $-\Delta H_{f}^{0}\left(\mathrm{MX}_{6}^{2-}, \mathrm{g}\right)$ & $\Delta H_{f}^{\circ}(\mathrm{M}, \mathrm{g})$ & $-\Delta H_{f}(\mathrm{M}-\mathrm{X})$ \\
\hline $\mathrm{Cs}_{2} \mathrm{ThCl}_{6}$ & 1492 & 1564 & 601.4 & 362 \\
\hline $\mathrm{Cs}_{2} \mathrm{PaCl}_{6}^{\circ}$ & 1502 & 1436 & 607 & 341 \\
\hline $\mathrm{Cs}_{2} \mathrm{UCl}_{6}^{\circ}$ & 1506 & 1414 & 531.4 & 325 \\
\hline $\mathrm{Cs}_{2} \mathrm{NpCl}_{6}$ & 1514 & 1372 & 464.8 & 307 \\
\hline $\mathrm{Cs}_{2} \mathrm{PuCl}_{6}$ & 1515 & 1366 & 345.2 & 286 \\
\hline $\mathrm{Cs}_{2} \mathrm{UBr}_{6}$ & 1456 & 1162 & 531.4 & 282 \\
\hline $\mathrm{Cs}_{2} \mathrm{NpBr}_{6}$ & 1457 & 1134 & 464.8 & 266 \\
\hline $\mathrm{Cs}_{2} \mathrm{PuBr}_{6}$ & 1461 & 1142 & 345.2 & 247 \\
\hline
\end{tabular}

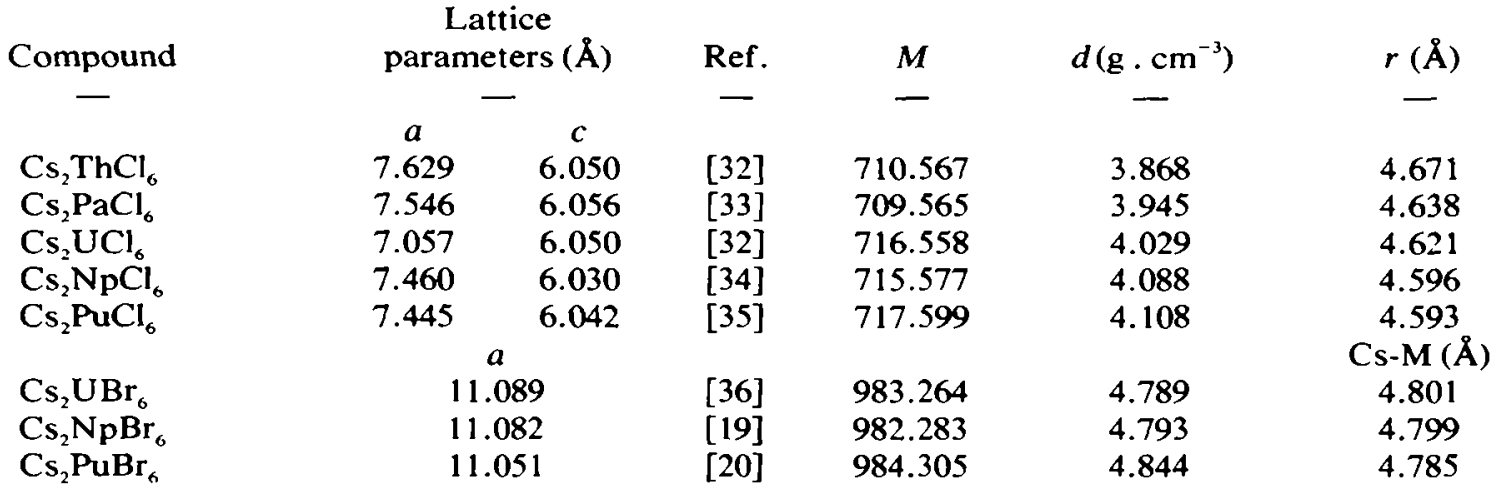

Table III. - Thermodynamic calculations on $\mathrm{Cs}_{2} \mathrm{MX}_{6}\left(\mathrm{~kJ} \cdot \mathrm{mol}^{-1}\right)$. 
It is obvious that the energetics of the $\mathrm{MX}_{6}^{2-}(\mathrm{g})$ species deserves more elaborate calculations such as those carried out by Jenkins and Pratt [37] for $\mathbf{M}_{2}^{\prime} \mathbf{M X}_{6}$ compounds of $\mathrm{d}$ transition and main group elements with the $\mathrm{K}_{2} \mathrm{PtCl}_{6}$ structure and indeed such calculations are tackled by these authors [38].

Table IV summarizes the few existing thermodynamic data for the chloro- and bromo-complexes of the actinides in the $\mathrm{V}$ and VI valency state.

Table IV. - Thermodynamic data associated with the formation of penta- and hexavalent actinides chloro-and bromo-complexes at $298 \mathrm{~K}\left(\mathrm{~kJ} . \mathrm{mol}^{-1}\right)$.

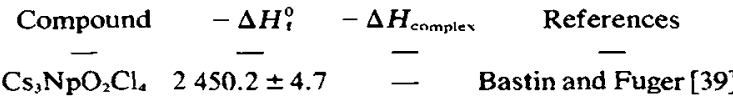

$$
\begin{aligned}
& \mathrm{Cs}_{2} \mathrm{UO}_{2} \mathrm{Cl}_{4} \quad 2204.5 \pm 2.5 \quad 75.7 \pm 0.5 \text { Tixhon and Fuger [40] } \\
& \mathrm{Cs}_{2} \mathrm{NpO}_{2} \mathrm{Cl}_{4} 2056.6 \pm 5.0 \quad(86 \pm 5) \text { Tixhon and Fuger [40] } \\
& \mathrm{Cs}_{2} \mathrm{UO}_{2} \mathrm{Br}_{4} \quad 2009.0 \pm 1.5 \quad 60.1 \pm 0.4 \text { Niffle and Fuger [20] }
\end{aligned}
$$

No value is given for $\Delta H_{\text {complex }}$ in the case of $\mathrm{Cs}_{3} \mathrm{NpO}_{2} \mathrm{Cl}_{4}$ as $\mathrm{NpO}_{2} \mathrm{Cl}$ is not known and because $\mathrm{UO}_{2} \mathrm{Cl}$ and $\mathrm{PaO}_{2} \mathrm{Cl}$ are the only such actinide (V) chlorides known with certainty. Similarly $\mathrm{NpO}_{2} \mathrm{Cl}_{2}$ has not been characterized but its enthalpy of formation can easily be estimated from that of $\mathrm{UO}_{2} \mathrm{Cl}_{2}$. The results in table IV can also be used as a good basis for the estimation of values on the plutonium and americium chloride analogues [1].

Although many chloro- and bromo-complexes of the actinides in the +3 valency are known, the thermodynamic data are scanty. An interesting class of compounds to note displays the general formula $\mathrm{Cs}_{2} \mathrm{NaMCl}_{6}$ : it can accommodate trivalent cations of almost any size (from $\mathrm{La}^{3+}$ to $\mathrm{Fe}^{3+}$ ) [41] while retaining the same high symmetry fcc structure with $\mathrm{MCl}_{6}^{2-}$ regular octahedra. Thermodynamics of these compounds throughout the lanthanide series has been thoroughly studied by Morss [42] who also obtained data for the plutonium analogue. From these data Morss and Goldman [43] derived values for the enthalpies of hydration of trivalent actinides (U-Bk inclusive) in excellent agreement with those obtained through the use of an electrostatic model.

4. Prevision of the stability of new halogenocomplexes. - The existence of $\mathrm{Cs}_{2} \mathrm{PuCl}_{6}(\mathrm{c})$, while $\mathrm{PuCl}_{4}$ has only been characterized in the gas phase and is unstable in the crystalline form toward decomposition into $\mathrm{PuCl}_{3}(\mathrm{c})$, the existence of $\mathrm{Cs}_{2} \mathrm{BkCl}_{6}$ (c) [3] and of the newly prepared $\mathrm{Cs}_{2} \mathrm{PuBr}_{6}$ [20], while $\mathrm{BkCl}_{4}$ and $\mathrm{PuBr}_{4}$ are not likely to be characterized, are interesting examples of stabilization of an actinide in a given valency state. Many such similar situations can be envisioned and discussed. We selected here to take as examples the case of the hypothetical $\mathrm{Cs}_{2} \mathrm{NpI}_{6}$ and $\mathrm{Cs}_{2} \mathrm{UO}_{2} \mathrm{I}_{4}$ compounds, because so far there are no thermodynamic data on actinide iodo-complexes.
The enthalpy of formation of the only known iodide of neptunium, $\mathrm{NpI}_{3}$, has recently been determined as $-512.8 \pm 2.1 \mathrm{~kJ}^{-} \mathrm{mol}^{-1}$ [44], while we can estimate

$$
\Delta H_{\varepsilon}^{\mathrm{o}}\left(\mathrm{NpI}_{4}, \mathrm{c}\right)=-494 \pm 20 \mathrm{~kJ} \cdot \mathrm{mol}^{-1}
$$

for this hypothetical compound.

We thus obtain for the hypothetical reaction (7)

$$
\mathrm{NpI}_{3}(\mathrm{c})+\frac{1}{2} \mathrm{I}_{2}(\mathrm{c}) \rightarrow \mathrm{NpI}_{4}(\mathrm{c})
$$

$\Delta H_{7}=+19 \pm 20 \mathrm{~kJ} \cdot \mathrm{mol}^{-1}$. We shall accept for this reaction

$$
\Delta S_{7}=-16 \pm 3 \mathrm{~J} \cdot \mathrm{K}^{-1} \cdot \mathrm{mol}^{-1}
$$

by analogy with the corresponding uranium system. For reaction (8)

$$
\mathrm{NpI}_{4}(\mathrm{c})+2 \mathrm{CsI}(\mathrm{c}) \rightarrow \mathrm{Cs}_{2} \mathrm{NpI}_{6}(\mathrm{c})
$$

we deduce from the known experimental data on the known chloro- and bromo-complexes,

$$
\Delta H_{8}=-90 \pm 10 \mathrm{~kJ} \cdot \mathrm{mol}^{-1}
$$

and accept $\Delta S_{\mathrm{s}} \geqslant-30 \mathrm{~J} \cdot \mathrm{K}^{-1} \cdot \mathrm{mol}^{-1}$ from the data of Latimer [45] on the entropies of analogous salts such as $\mathrm{K}_{2} \mathrm{PtCl}_{6}, \mathrm{~K}_{2} \mathrm{PtBr}_{6}, \mathrm{~K}_{3} \mathrm{IrCl}_{6} \ldots$ Therefore we obtain for reaction (9), which is the sum of reactions (7) and (8)

$$
\begin{gathered}
\mathrm{NpI}_{3}(\mathrm{c})+\frac{1}{2} \mathrm{I}_{2}(\mathrm{c})+2 \mathrm{CsI}(\mathrm{c}) \rightarrow \mathrm{Cs}_{2} \mathrm{NpI}_{6}(\mathrm{c}) \\
\Delta H_{9}=-71 \pm 22 \mathrm{~kJ} \cdot \mathrm{mol}^{-1} \\
\Delta S_{\varphi} \geqslant-46 \mathrm{~J} \cdot \mathrm{K}^{-1} \cdot \mathrm{mol}^{-1}
\end{gathered}
$$

and

$$
\Delta G_{9} \leqslant-57 \pm 22 \mathrm{~kJ} \cdot \mathrm{mol}^{-1}
$$

indicating that $\mathrm{Cs}_{2} \mathrm{NpI}_{6}(\mathrm{c})$ should be stable toward iodine evolution. As $\mathrm{Np}(\mathrm{IV})$ is the only species stable in an aqueous medium in presence of the $\mathrm{I}_{2} / \mathrm{I}^{-}$ couple, this route appears to be the first choice to make if the synthesis is attempted.

Although $\mathrm{UO}_{2} \mathrm{I}_{2}$ adducts with organic molecules have been reported [1], the preparation of this compounds and its hydrates has been attempted several times without success. Brandenburg [46] suggested through a correlation method involving numerous compounds a value of $-1000 \pm$ $4 \mathrm{~kJ} . \mathrm{mol}^{-1}$ for its enthalpy of formation. In view of the accepted value for $\Delta H_{1}^{0}\left(\mathrm{UO}_{2}, \mathrm{c}\right),-1084.9 \pm$ $0.8 \mathrm{~kJ} . \mathrm{mol}^{1}[22]$, it is clear that $\mathrm{UO}_{2} \mathrm{I}_{2}(\mathrm{c})$ should be unstable toward $\mathrm{UO}_{2}(\mathrm{c})+\mathrm{I}_{2}(\mathrm{c})$ : therefore for $\mathrm{Cs}_{2} \mathrm{UO}_{2} \mathrm{I}_{4}$ (c) to be stable with respects to $\mathrm{UO}_{2}(\mathrm{c})$, its formation from $\mathrm{CsI}(\mathrm{c}), \mathrm{UO}_{2}(\mathrm{c})$ and $\mathrm{I}_{2}(\mathrm{c})$ should be accompanied by an enthalpy effect more negative 
than $-85 \mathrm{~kJ} \cdot \mathrm{mol}^{-1}$, which appears unlikely in view of the data obtained for $\mathrm{Cs}_{2} \mathrm{UO}_{2} \mathrm{Cl}_{4}$ and $\mathrm{Cs}_{2} \mathrm{UO}_{2} \mathrm{Br}_{4}$. Let us note, however, that the synthesis of an analogous iodo-complex with a large organic cation (triphenylbutylphosphonium) has been obtained by crystallization from an organic medium [1].

Finally, it is certainly appropriate to evoke the possibilities of stabilization of the lower valency states of the actinides through the formation of halogeno-complexes of the type $\mathrm{CsMX}_{3}$. None of these compounds have been prepared, yet, for the actinides but such studies on the lanthanides are presently carried out by Morss [47]: preliminary experiments indicate that a reaction such as

$$
\mathrm{CsCl}(\mathrm{c})+\mathrm{DyCl}_{2}(\mathrm{c}) \rightarrow \mathrm{CsDyCl}_{3}(\mathrm{c})
$$

corresponds to a $\Delta H_{10}$ of $-28 \pm 15 \mathrm{~kJ} \cdot \mathrm{mol}^{-1}$ which is very small. Therefore hopes to obtain more easily divalent actinides by stabilization in a chloride complex salt of caesium appear scanty. However, these systems deserve further studies, particularly with regard to bromides and iodides and also to other univalent ions.

\section{References}

[1] BRown, D., Halides of the Lanthanides and Actinides (London, Wiley and Sons) 1968.

[2] Penneman, R. A., Ryan, R. R., Rozenzweig, A., Structural Systematics in Actinide Fluoride Complexes, in Structure and Bonding, vol. 13 (Springer Verlag, Berlin-New York) 1973.

[3] Brown, D., The Actinide Halides, in MTP International Review of Science, Series One, Inorganic Chemistry, vol. 7 (Butterworths, London) 1972.

[4] Mukhametshina, Z. B., Suponitskil, Yu. L., Seleznev, V. P., Bodrov, V. G., Karapet'yants, M. Th., SudaRIKOV, B. N., Russ. J. Inorg. Chem. 19 (1974) 257.

[5] Suponitskir, Yu. L., Seleznev, V. P., Mukhametshina, Z. B., Bodrov, V. G., KarapeT'Yants, M. Kh., SudaRIKOV, B. N., Sov. Radiochem. 16 (1974) 84.

[6] Mukhametshina, Z. B., Seleznev, V. P., SuponitskiI, Yu. L., Bodrov, V.G., KarapeT'Yants, M. Kh., SUDARIKOV, B. N., Russ. J. Phys. Chem. 48 (1974) 293.

[7] KATZ, S., Inorg. Chem. 3 (1964) 1598 ; 5 (1966) 666.

[8] Malm, J. G., Selig, H., Siegel, S., Inorg. Chem. 5 (1966) 130.

[9] Peka, I., Sedlakova, L., Sykora, F., Coll. Czech. Chem. Commun. 31 (1966) 4449.

[10] Cathers, G. I., BennetT, M. R., Jolley, R. L., Ind. Eng. Chem. 50 (1958) 1709.

[11] Trevorrow, L. E., Riha, J. G., Steindler, M. J., J. Inorg. Nucl. Chem. 33 (1971) 2875.

[12] Chauvenet, E., Ann. Chim. Phys. 23 (1911) 425.

[13] Fuger, J., Brown, D., J. Chem. Soc. (A) (1971) 841.

[14] Fuger, J., Brown, D., J. Chem. Soc. Dalton (1975) 2256.

[15] Martynova, N. S., Kudryashova, Z. P., Vasil'Kova, I. V. At. Energ. 25 (1968) 226.

[16] Vdovenko, V. M., Volkov, V. A., Suglobova, I. G., Sov. Radiochem. 16 (1974) 364.

[17] Vdovenko, V. M., Suglobova, I. G., Chirkst, D. E., Sov. Radiochem. 15 (1973) 56.

[18] Vdovenko, V. M., Suglobova, I. G., Chirkst, D. E., Sov. Radiochem. 16 (1974) 205.

[19] MAGETTE, M., FUGER, J., Inorg. Nucl. Chem. Lett. 13 (1977) 529.

[20] NiffLe, A., FUger, J., unpublished results.

[21] HubBard, W. N., Fuger, J., OetTing, F. L., Parker, V. B., in The Chemical Thermodynamics of Actinide Elements and Compounds, Part 9: The Actinide Halides (in preparation), International Atomic Agency, Vienna. Finally assessed values may differ somewhat from the values indicated here, but the difference is expected to remain within the specified uncertainty limits.
[22] CODATA Recommended Key-values for Thermodynamics (1977). Codata Bulletin $\mathrm{n}^{\circ}$ 28, April 1978, CODATA Secrétariat, 51, Bd. de Montmorency, 75016 Paris.

[23] Parker, V. B., Wagman, D. D., Garvin, D., Natl. Bur. Stand. Rep. NBSIR 75-968 (1976).

[24] Fuger, J., Brown, D., J. Chem. Soc. (A) (1970) 763.

[25] Fuger, J., Brown, D., J. Chem. Soc. Dalton (1973) 428.

[26] The Chemical Thermodynamics of Actinide Elements and Compounds. OetTing, F. L., RAND, M. H., ACKerman, R. J., Part 1 : The Actinide Elements (1976) ; FugER, J., Oetting, F. L., Part 2: The Actinide Aqueous Ions (1976). International Atomic Energy Agency, Vienna.

[27] Hultgren, M., Desai, P. D., Hawkins, D. T., Gleiser, M., KELLEY, K. K., WAGMAN, D. D., Selected Values of the Thermodynamic Properties of the Elements (American Society of Metals, Metals Park, Ohio) 1973.

[28] Rosenstock, H. M., DraXL, K., Steiner, B. W., Herron, J. T., J. Phys. Chem. Ref. Data 6 (1977) suppl. 1.

[29] Hotop, H., Lineberger, W. C., J. Phys. Chem. Ref. Data 4 (1975).

[30] Yatsimirskit, K. B., Russ. J. Inorg. Chem. 6 (1961) 265.

[31] YATSIMIRSKII, K. B., Zh. Obshch. Khim. 17 (1947) 2019.

[32] SIEGEL, S., Acta Crystallogr. 9 (1956) 827.

[33] Brown, D., Jones, P. J., J. Chem. Soc. (A) (1967) 243.

[34] Bagnall, K. W., LaidleR, B. J., J. Chem. Soc. (A) (1966) 516.

[35] Zachariasen, W. H., Acta Crystallogr. 1 (1948) 268.

[36] VDOVEnko, V. M., KOzHINA, I. I., SUGlobova, I. G. CHIRKsT, D. E., Sov. Radiochem. 15 (1973) 53. This lattice parameter has been recalculated from the original data.

[37] Jenkins, H. D. B., Pratt, K. F., Adv. Inorg. Chem. Radiochem. 22 (1978).

[38] Jenkins, H. D. B., Pratt, K. F., Private communication.

[39] Bastin, C., FugER, J., Unpublished results.

[40] TIXHON, C., FugER, J., Unpublished results.

[41] Morss, L. R., Siegal, M., Stenger, L., Edelstein, N., Inorg. Chem. 9 (1970) 1771.

[42] Morss, L. R., J. Phys. Chem. 75 (1971) 392.

[43] Morss, L. R., Goldman, S., Can. J. Chem. 53 (1975) 2695.

[44] Hurtgen, C., Fuger, J., Brown, D., Unpublished results.

[45] Latimer, W. M., Oxidation Potentials (Prentice HallEnglewood Cliffs, N.J.) 1952.

[46] Brandenburg, N. P., Thesis, Amsterdam (June 1978).

[47] Morss, L. R., FAHeY, J. A., Nocera, D., Crowther, D., TOM, L., PORCJA, R., Paper presented at the 32nd Annual Calorimetry Conference July 1977, Sherbrooke, Canada ; MoRss, L. R., private communication. 


\section{DISCUSSION}

Dr. FORREST L. CARTER. - I have several questions :

1) In your application of semiempirical calculations of lattice energy have you had occasion to make use of the approximation given by Templeton based on coordination number.

2) In the rare earths the very interesting series of «Vernier » phases have been recently discovered. Is these any evidence of similar material among the actinide halides.

3) Also among the reduced rare earth halides is the very interesting linear conductor $\mathrm{Gd}_{2} \mathrm{Cl}_{3}$ in which a conducting metal chain is surrounded by an insulating layer of halides. Such a compound isolated among the actinides should be very interesting to the physicists in regard to dimensional spin waves and $f$ delocalization, etc

J. FUGER. - 1) Although I am aware of the approximation given by Templeton, I have not attempted to make use of it as here my only purpose was evaluate trends in the $\mathrm{MX}_{6}^{2-}$ energetics.

2) I do not think that similar phases have been characterized as yet for the pure actinides. A lanthanide-actinide mixture containing californium (II) was reported by Haire et al. last fall at the rare earth research conference in the U.S.

3) I certainly agree fully with you. A lot of such compounds containing lanthanides in formally non integral oxidation states $(1.5,2.2, \ldots)$ have been reported by several authors (Bärnighausen, Eick, Haschke...).

Indeed future efforts towards studying such compounds of actinides should be scientifically rewarding.

Pr. P. PYYKKö. - Do you have any feeling for the amount of covalent character in the $\mathrm{MX}_{6}^{2-}$ group ? If I am not mistaken, in the alkali hexachloroplumbates you can actually see the hindered rotations of the $\mathrm{PbCl}_{6}^{2-}$ group by NMR, which indicates the existence of a tightly bound, well defined group. Also, every- one would agree that $\mathrm{UF}_{6}$ is covalent and adding a couple of electrons should not change the bonding very much.

J. FUGER. - Indeed the actinide hexahalogeno species can be considered as tightly bound species ; the $\mathrm{MX}_{6}^{2-}$ species is well known in solution. It is however difficult to ascertain the amount of covalent character and the stimulating discussions during this conference have shown that this matter is still pending.

Pr. J. R. PETERSON. - With respect to the complex halide salts of the type $\mathrm{Cs}_{2} \mathrm{AnX}_{6}$, which halide provides the greatest stabilization of the An(IV) ? In particular, how can I best stabilize Es(IV) in such a complex halide salt ?

J. FUGER. - Without any doubt, if I was to select a halide for that purpose I would choose fluoride. Alkali metal lanthanide and earlier actinide (IV) fluoride salts have been reported quite a number of years ago. The review cited as reference [2] in my paper would be very useful in selecting possible synthesis routes. It is also relevant to recall the early work of Asprey and coworkers on sodium praseodymium (IV) fluorides [ASPREY, L. B. and KEENAN, T. K., J. Inorg. Nucl. Chem. 16 (1961) 260] and on caesium dysprosium (IV) heptafluoride [VARgA, L. P. and Asprey, L. B., J. Chem. Phys. 48 (1968) 139].

Pr. BERTAUT. - The formula of Yatsimirskii, is it empirical or electrostatic?

J. FUGER. - The Yatsimirskii formula (Ref. [30]) is a refinement of the Kapustinskii's equation [KAPUSTINSKII, A. F., Zhur. Obshch. Khim. 13 (1943) 497] which was derived from the Born electrostatic model with empirical correction factors.

Another relevant reference concerning this equation is KapUstinskiI, A. F., Quart. Revs. (Chem. Soc. London) 10 (1956) 283. 